\title{
Hubungan Konsep Diri dan Kepercayaan Diri Dengan Hasil Belajar Simulasi Komunikasi dan Digital Siswa
}

\author{
Husnal Hafizah ${ }^{1 *}$, Ambiyar ${ }^{2}$ (iD \\ 1,2 Jurusan Pendidikan Teknologi Kejuruan, Universitas Negeri Padang, Padang, Indonesia \\ *Corresponding author: husnalhafizah239@gmail.com
}

\begin{abstract}
Abstrak
Hasil belajar siswa pada pelajaran simulasi komunikasi digital kelas X TKJ masih banyak yang belum mencapai KKM. Penelitian ini bertujuan untuk menganalisis hubungan konsep diri dan kepercayaan diri dengan hasil belajar simulasi komunikasi dan digital siswa kelas X TKJ SMK. Jenis penelitian adalah kuantitatif dengan pendekatan korelasional. Populasi penelitian ini adalah semua siswa kelas X TKJ di SMK. Populasi penelitian berjumlah 35 siswa. Pengambilan sampel dalam penelitian ini dilakukan dengan cara total sampling dengan jumlah sampel 35 . Instrumen pengumpulan data menggunakan kuisioner menggunakan Skala Likert, teknik analisis data diantaranya korelasi sederhana dan korelasi berganda. Hasil penelitian menunjukkan bahwa terdapat hubungan yang positif dan signifikan antara konsep diri dengan hasil belajar yang kuat, terdapat hubungan yang positif dan signifikan antara kepercayaan diri dengan hasil belajar yang kuat dan terdapat hubungan yang positif dan signifikan antara konsep diri dan kepercayaan diri dengan hasil belajar yang kuat. Penelitian diharapkan dapat meningkatkan hasil belajar melalui peningkatan konsep diri positif dan kepercayaan diri yang potif, sehingga siswa terdorong melakukan kegiatan yang positif dalam belajar.
\end{abstract}

Kata kunci: Hasil Belajar, Konsep Diri, Kepercayaan Diri

\section{Abstract}

There are still many student learning outcomes in digital communication simulation lessons for class $X$ TKJ that have not yet reached the KKM. This study aims to explain the relationship between self-concept and self-confidence with learning outcomes of communication simulation and digital students of class X TKJ SMK. This type of research is quantitative with a correlational approach. The population of this study were all students of class X TKJ at SMK. The study population was 35 students. Sampling in this study was carried out by total sampling with a sample size of 35 . The data collection instrument used a questionnaire using a Likert scale, data analysis techniques including simple correlation and multiple correlation. The results showed that there is a positive and significant relationship between self-concept and strong learning outcomes, there is a positive and significant relationship between self-confidence and strong learning outcomes. there is a positive and significant relationship between self-concept and self-confidence with strong learning outcomes. Research is expected to improve learning outcomes through increasing positive self-concept and potential self-confidence, so that students are encouraged to do positive activities in learning.

Keywords: Learning Outcomes, Self Concept, Self Confidence

History:
Received : 3 Januari 201
Revised : 20 Januari 2021
Accepted : 14 Februari 2021
Published : 25 Maret 2021

Pendahuluan

Perkembangan teknologi di era globalisasi menyebabkan lembaga pendidikan harus mencapai perubahan budaya, strategi dan operasional. Lembaga pendidikan harus mengupayakan perubahan yang relevan dengan kebutuhan persiapan dan proses belajar peserta didik abad 21 untuk mencapai kualitas lulusan yang kompeten dalam mengisi kesempatan karir berskala nasional bahkan Internasional (Dewi, 2020). Upaya ini bertujuan
Licensed: This work is licensed under a Creative Commons Attribution 4.0 License (c) (7) (? 
untuk mengatasi hambatan internal seperti budaya pendidikan lama yang teoritis, keterbatasan inovasi pembelajaran SDM tenaga pendidik, lemahnya penguasaan teknologi dalam pendidikan dan manajemen perubahan lembaga pendidikan yang tidak menyesuaikan tuntutan globalisasi (Tjandrawinata, 2016)

Mata Pelajaran Simulasi dan Komunikasi Digital merupakan salah satu mata pelajaran yang diajarkan kepada siswa di SMK. Mata pelajaran ini merupakan alat untuk mengkomunikasikan konsep dan gagasan melalui presentasi digital (Fitriani, 2018; Indahini et al., 2018). Melalui pelajaran simulasi dan komunikasi digital diharapkan dapat memberikan berbagai keterampilan bagi siswa melalui alat-alat, selain itu dapat membantu mempermudah pekerjaan dalam bidang-bidang tertentu (Rahmadhani et al., 2021). Program pembelajaran siswa SMK diharapkan mengembangkan program pemberdayaan yang sesuai dengan perkembangan lapangan kerja yang telah mengikuti standar yang telah ditetapkan secara nasional maupun internasional (Dewi, 2020; Zikri, 2020). Oleh karena itu, hasil belajar yang diperoleh dalam proses pembelajaran menjadi tolak ukur dalam proses pembelajaran dan keberhasilan dalam menghasilkan generasi penerus yang berkualitas (E. Nur, 2020). Sesuai dengan petunjuk dari Badan Standar Nasional Pendidikan (BSNP) tahun 2006 setiap sekolah boleh menentukan standar ketuntasan sekolah masing-masing, sehingga sekolah-sekolah pada umumnya menetapkan standar ketuntasan belajar dengan nilai 70,00 untuk semua mata pelajaran.

Faktor yang mempengaruhi hasil belajar siswa dapat dipengaruhi oleh konsep diri dan kepercayaan diri. Konsep diri menjadi faktor intern yang dapat mempengaruhi hasil belajar siswa, emosi sosial siswa serta konsep diri dapat membantu siswa menjadi lebih percaya diri dalam mengikuti kegiatan pembelajaran (Harahap, 2017; Nugroho, 2015). Hal ini menunjukkan siswa yang mempunyai konsep diri tinggi akan menilai dirinya secara baik (positif), semangat yang tinggi, optimis, mudah menerima pelajaran dan merasa mampu serta lebih percaya diri untuk mencapai prestasi (Gunarsih, 2016). Sehingga, konsep diri mempunyai peran penting dalam keterlibatannya dalam proses kegiatan pembelajaran serta menentukan prilaku individu (Handayani, 2017). Faktor lain yang mempengaruhi yaitu kepercayaan diri, perbedaan tingkat kepercayaan diri yang dimiliki siswa tentu akan mempengaruhi perolehan prestasi belajar dan siswa yang memiliki percayaan diri yang baik selalu berusaha mengembangkan potensi secara maksimal serta selalu menunjukkan yang terbaik dari dirinya (Amri, 2018; Komara, 2016). Oleh karena itu, kepercayaan diri sangat penting untuk mendorong siswa meraih keberhasilan dalam lingkungannya (Puspitasari, 2012).

Berdasarkan hasil observasi awal dimana hasil belajar mata pelajaran simulasi komunikasi dan digital yang diperoleh siswa pada umumnya masih di bawah KKM yang ditetapkan oleh sekolah. Selain itu, konsep diri dan kepercayaan diri memiliki dampak terhadap hasil belajar siswa. Adanya kepercayaan diri yang intensif maka akan terbentuk konsep diri yang positif dalam diri siswa yang mengakibatkan siswa lebih giat dan bersemangat dalam belajar.

Penelitian ini didukung oleh temuan yang menyatakan bahwa Pola asuh orang tua, konsep diri dan motivasi berprestasi secara bersama-sama berpengaruh positif terhadap prestasi bealar matematika (A. S. Nur, 2016). Temuan lain juga menunjukkan bahwa terdapat pengaruh konsep diri terhadap hasil belajar matematika (Handayani, 2017; Haryaka, U., 2019). Komara (2016) menemukan ada hubungan positif antara kepercayaan diri dan prestasi belajar dengan perencanaan karir siswa kelas VIII SMPN 3 Bantul. Amri (2018) menunjukkan bahwa kepercayaan diri berbasis ekstrakurikuler pramuka berpengaruh terahadap prestasi belajar siswa di SMAN Negeri 6 bengkulu.

Berdasarkan uraian yang telah dipaparkan di atas, hasil belajar simulasi komunikasi dan digital pengaruhnya dengan konsep diri dan kepercayaan siswa merupakan masalah yang 
perlu untuk diteliti. Oleh karena itu, tujuan penelitian ini menganalisis hubungan yang positif dan signifikan antara konsep diri dan kepercayaan diri dengan hasil belajar simulasi komunikasi dan digital siswa kelas X TKJ SMK Negeri 1 Painan. Hasil penelitian ini diharapkan mampu memberi konstribusi yang signifikan dalam upaya pengoptimalan pembelajaran simulasi komunikasi dan digital.

\section{Metode}

Penelitian ini menggunakan metode kuantitatif melalui pendekatan korelasional. Deskriptif korelasional merupakan suatu penelitian yang dirancang untuk menentukan tingkat hubungan variabel-variabel yang berbeda dalam suatu populasi (Arikunto, 2013). Populasi penelitian ini adalah semua siswa kelas $X$ TKJ di SMKN 1 Painan. Populasi penelitian berjumlah 35 siswa. Teknik pengambilan sampel menggunakan teknik total sampling sehingga sampel sebesar 35 responden. Sumber data yang digunakan yaitu data primer merupakan data yang secara langsung diperoleh dari hasil penyebaran angket kepada responden, yaitu mahasiswa. Instrumen yang digunakan dalam penelitian yaitu angket dengan menggunakan skala likert. Teknik analisis data yang digunakan yaitu (1) deskripsi data yaitu skor mean (nilai rerata), median, modus, dan standar deviasi. (2) pengujian persyaratan analisis yaitu uji normalitas, uji homogenitas, uji linearitas dan pengujian independensi veriabel bebas. (3) Hipotesis menggunakan korelasi sederhana dan korelasi berganda.

\section{Hasil dan Pembahasan}

Berdasarkan data yang diperoleh uji hipotesis dilakukan dengan menggunakan teknik analisis korelasi sederhana untuk menguji hubungan antara konsep diri dengan hasil belajar dan hubungan antara kepercayaan diri dengan hasil belajar. Analisis korelasi berganda untuk menguji hubungan konsep diri dan kepercayaan diri dengan hasil belajar. Berdasarkan hasil penelitan maka dapat rangkum pada Tabel 1.

Tabel 1. Hasil Analisis Korelasi sederhana dan korelasai bergandaAntara konsep diri (X2) dengan hasil belajar (Y)

\begin{tabular}{ccccc}
\hline Korelasi & Koefisien korelasi (r) & Korefisien dererminasi $\left(\mathbf{r}^{2}\right)$ & Kontribusi & $\rho$ \\
\hline $\operatorname{Ryx}_{1}$ & 0,777 & 0,604 & $60.4 \%$ & 0,000 \\
$\operatorname{Ryx}_{2}$ & 0,639 & 0,408 & $40.8 \%$ & 0,000 \\
$\operatorname{ryx}_{1} \mathrm{x}_{2}$ & 0,822 & 0,676 & $67,6 \%$ & 0,00 \\
\hline
\end{tabular}

Hasil perhitungan pada Tabel 1 menunjukkan bahwa koefsien korelasi $\left(\operatorname{ryx}_{1}\right)=0,777$ dengan $\rho=0,000<\alpha=0,05$. Ini berarti bahwa terdapat hubungan yang signifikan antara konsep diri dengan hasil belajar yang kuat. Besarnya koefisien determinasi $\left(\mathrm{r}^{2}\right)$ sebesar 0,604. Besarnya kontribusi konsep diri dengan hasil belajar simulasi komunikasi dan digital siswa kelas X TKJ SMK Negeri 1 Painan adalah sebesar 60,4\%.

Hipotesis kedua yang akan diuji dalam penelitian ini adalah terdapat hubungan positif yang signifikan antara kepercayaan diri dengan hasil belajar simulasi komunikasi dan digital siswa kelas X TKJ SMK Negeri 1 Painan. Sesuai dengan hasil perhitungan diperoleh koefisien korelasi kepercayaan diri denganp hasil belajar adalah sebesar 0,639. Koefsien korelasi (ryx) $=0,639$ dengan $\rho=0,000<\alpha=0,05$. Ini berarti bahwa terdapat hubungan yang positif dan signifikan antara kepercayaan diri dengan hasil belajar yang kuat. Besarnya koefisien determinasi $\left(\mathrm{r}^{2}\right)$ sebesar 0,408. Besarnya kontribusi kepercayaan diri dengan hasil belajar simulasi komunikasi dan digital siswa kelas X TKJ SMK Negeri 1 Painan adalah sebesar $40.8 \%$. 
Hipotesis ketiga yang akan diuji dalam penelitian ini adalah terdapat hubungan positif yang signifikan antara konsep diri dan kepercayaan diri dengan hasil belajar simulasi komunikasi dan digital siswa kelas X TKJ SMK Negeri 1 Painan. Sesuai dengan hasil perhitungan diperoleh koefisien korelasi konsep diri dan kepercayaan diri dengan hasil belajar adalah sebesar 0,822 . Koefsien korelasi $\left(\operatorname{ryx}_{1} x_{2}\right)=0,882$ dengan $\rho=0,000<$ $\alpha=0,05$. Ini berarti bahwa terdapat hubungan yang positif dan signifikan antara hasil belajar, konsep diri dan kepercayaan diri dengan hasil belajar yang kuat. Besarnya koefisien determinasi $\left(\mathrm{r}^{2}\right)$ sebesar 0,676. Besarnya kontribusi konsep diri dan kepercayaan diri dengan hasil belajar simulasi komunikasi dan digital siswa kelas X TKJ SMK Negeri 1 Painan adalah sebesar $67,6 \%$.

Berdasarkan hasil penelitian, terdapat hubungan konsep diri dengan hasil belajar. Adanya hubungan antara konsep diri dan kepercayaan diri terhadap hasil belajar siswa, terlihat bahwa konsep diri yang dimiliki siswa sudah mengarah pada konsep diri yang positif, dengan demikian hasil belajar yang diperoleh cukup baik. Sebaliknya, pada siswa yang menunjukkan konsep diri rendah atau negatif, akan memandang lingkungan sekitarnya negatif. Konsep diri siswa yang positif menyebabkan siswa yakin pada kemampuan dirinya secara optimal dalam menyelesaikan tugas-tugas pelajaran, selain itu siswa lebih optimis, percaya diri dan selalu bersikap positif terhadap sesuatu, termasuk dalam menghadapi kegagalan yang dialaminya, serta melakukan sesuatu demi keberhasilan di masa depan. Konsep diri berkaitan dengan perasaan siswa rasakan seperti gambaran, cara pandang, keyakinan, pemikiran, dan perasaan terhadap apa yang dimiliki orang tentang dirinya sendiri selain itu peserta didik yang memiliki konsep diri positif cenderung berhasil secara akademis, sosial dan fisik (Pucangan, 2017; Sumyati, 2017). Perkembangan konsep diri seseorang sangat tergantung dari penagalamn dan pengetahuan seseorang. Semakin banyak pengalaman dan pengetahuan seseorang maka konsep dirinya akan berkembang kearah yang positf dan produktif (Budiarnawan, 2014).

Berdasarkan hasil penelitian, terdapat hubungan kepercayaan diri terhadap hasil belajar. Adanya hubungan ini terlihat pada aktivitas pembelajaran tugas siswa harus diselesaikan atau masalah-masalah harus dipecahkan atas dasar kemampuan siswa sendiri. Sebagai upaya membimbing siswa kearah tanggung jawab sendiri, ini berarti siswa akan terbina untuk percaya kepada diri sendiri, mampu mengatasi kesulitan-kesulitan dengan kemampuan sendiri, penuh inisiatif, kreatif dan berfikir kritis serta bertanggung jawab. Hal lain, ditunjukkan dalam proses pembelajaran, siswa yang memiliki rasa percaya diri yang tinggi cenderung lebih mudah menerima pelajaran dibandingkan dengan siswa yang tidak memiliki rasa percaya diri. Siswa yang memiliki kepercayaan diri yang tinggi akan cenderung lebih aktif di kelas, sedangkan siswa dengan kepercayaan diri yang rendah akan cenderung lebih pasif di dalam kelas (Murtiningsih, 2017; Panjaitan, 2020). Dari penjelasan tersebut jelas bahwa kepercayaan diri berpengaruh terhadap hasil belajar.

Terdapat hubungan konsep diri dan percaya diri terhadap hasil belajar simulasi komunikasi dan digital. Karena kepercayaan diri diawali oleh konsep diri. Konsep diri adalah gagasan seseorang tentang dirinya sendiri, yang memberikan gambaran kepada seseorang mengenal kepada dirinya sendiri. Kepercayaan diri yang dimiliki siswa sangat berhubungan dengan penentuan dan peningkatan hasil belajar mata pelajaran simulasi komunikasi digital. Dengan adanya kepercayaan diri dari siswa akan membuat siswa lebih aktif dan kreatif dalam menyelesaikan masalah dalam proses. Proses belajar ini dipengaruhi oleh faktor eksternal dan internal dari siswa, sehingga diperlukan suatu konsep belajar yang sesuai dengan kondisi siswa, sehingga hasil belajar yang diinginkan tercapai.

Hasil penelitian ini didukung oleh temuan penelitian yang menunjukkan konsep diri dan berhubungan secara signifikan terhadap hasil belajar (Handayani, 2017; Haryaka, U., 
2019; A. S. Nur, 2016; Pucangan, 2017). Temuan lain yang menemukan terdapat pengaruh kepercayaan diri terhadap hasil belajar (Indriawati, 2018). Temuan penelitian Rozaini (2017) menyatakan bahwa kepercayaan diri berpengaruh secara signifikan terhadap prestasi belajar. Tingkat kepercayaan diri berpengaruh positif dan signifikan terhadap hasil belajar (Komara, 2016; Nurhidayah, 2019). Temuan penelitian terdahulu terlaksana pada lembaga pendidikan SD, SMP, dan SMA memperoleh hasil yang sisgnifikan hubungan antara konsep diri dan kepercayaan diri terhadap hasil belajar siswa. Hasil penelitian ini menemukan hubungan konsep diri dan kepercayaan diri terhadap hasil belajar ditemukan juga pada lembaga pendidikan SMK. Penelitian ini memiliki keterbatasan yaitu sampel penelitian yang digunakan sedikit dengan jumlah 35 siswa. Untuk penelitian selanjutnya dapat menambah jumlah responden, sehingga hasil yang diperoleh menjadi lebih maksimal

\section{Simpulan}

Berdasarkan hasil penelitia, dapat disimpulkan bahwa terdapat hubungan yang positif dan signifikan antara konsep diri dengan hasil belajar yang kuat. Terdapat hubungan yang positif dan signifikan antara kepercayaan diri dengan hasil belajar yang kuat. Terdapat hubungan yang positif dan signifikan antara konsep diri dan kepercayaan diri dengan hasil belajar yang kuat. Ada hubungan positif yang signifikan antara konsep diri dan kepercayaan diri terhadap hasil belajar siswa. Siswa mengalami permasalahan di sekolah pada umumnya menunjukkan tingkat konsep diri yang rendah. Oleh sebab itu, dalam rangka meningkatkan kualitas pendidikan di sekolah guru perlu melakukan upaya yang memungkinkan terjadinya peningkatan konsep diri siswa dengan menerapkan beberapa strategi yang perlu dilakukan guru diantaranya membuat siswa merasa mendapat dukungan dari guru, membuat siswa merasa tanggung jawab, membuat ssiwa merasa mampu, mengarahkan siswa untuk mencapai tujuan realistis, membantu siswa untuk menilai diri mereka secara realistis dan mendorong siswa agar bangga dengan dirinya.

\section{Daftar Rujukan}

Amri, S. (2018). Pengaruh Kepercayaan Diri (Self Confidence) Berbasis Ekstrakurikuler Pramuka Terhadap Prestasi Belajar Matematika Siswa Sma Negeri 6Kota Bengkulu. Jurnal Pendidikan Matematika Raflesia, 3(2). https://doi.org/10.33449/jpmr.v3i2.7520.

Arikunto. (2013). Prosedur Penelitian, Suatu Pendekatan Praktek. Rineka Cipta.

Asiyah. (2019). Pengaruh Rasa Percaya Diri Terhadap Motivasi Berprestasi Siswa pada Mata Pelajaran IPA. Jurnal Pendidikan Dan Kebudayaan, 9(3), 217-226. https://doi.org/10.24246/j.js.2019.v9.i3.p217-226.

Budiarnawan, A. (20.14). Hubungan Antara Konsep Diri dan Pola Asuh Orang Tua Terhadap Hasil Belajar IPA Siswa Kelas V SD di Desa Selat. MIMBAR PGSD Undiksha, 2(2). https://doi.org/10.23887/jjpgsd.v2i1.2224.

Dewi, M. (2020). Pengaruh Kemampuan Manusia Abad 12 Dengan Pembentukan Karakter Wirausaha Mahasiswa Universitas Putra Indonesia YPTK Padang. Jurnal Benefita, $5(3)$, 468-478. http://ejournal.1ldikti10.id/index.php/benefita/article/viewFile/5576/1912.

Fitriani, N. (2018). Pengembangan Media Computer Assisted Instruction Pada Mata Pelajaran Simulasi Dan Komunikasi Digital Materi Pokok Presentasi Video Untuk Branding Dan Marketing Kelas X Akuntasi Keuangan Di SMK Yapalis Krian Sidoarjo. Jurnal Mahasiswa Teknologi Pendidikan, 9(2), 1-10.

Gunarsih, F. D. (2016). Hubungan Interaksi Sosial, Konsep Diri, Dan Kecerdasan Emosional Terhadap Prestasi Belajar Matematika Siswa Kelas VIII SMP Negeri DI Kecamatan Pituruh. EKUIVALEN, 20(2), $211-216$. 
https://doi.org/10.37729/ekuivalen.v20i3.2901.

Handayani. (2017). Pengaruh Perhatian Orang Tua Dan Konsep Diri Siswa Terhadap Hasil Belajar Matematika Siswa. Jurnal Pendidikan Dasar, 8(1). http://journal.unj.ac.id/unj/index.php/jpd/article/view/5347.

Harahap, S. K. \& H. S. (2017). Hubungan Konsep Diri Dan Kecerdasan Emosional Terhadap Hasil Belajar Biologi Siswa Di Kelas XI IPA SMA. Jurnal Pendidikan Biologi, 6(3), 361-366. https://doi.org/10.24114/jpb.v6i3.8041

Haryaka, U., H. (2019). Pengaruh Konsep Diri, Minat dan Sikap Ilmiah Siswa terhadap Hasil Belajar Matematika. PRISMA, Prosiding Seminar Nasional Matematika, 2, 737-774. https://journal.unnes.ac.id/sju/index.php/prisma/article/view/29261.

Indahini, R. S., Sulton, \& Husna, A. (2018). Pengembangan Multimedia Mobile Learning Pada Mata Pelajaran Simulasi Dan Komunikasi Digita Kelas X SMK. Jurnal Kajian Teknologi Pendidikan, 1(2), 141-148. http://journal2.um.ac.id/index.php/jktp/article/view/3730.

Indriawati, P. (2018). Pengaruh Kepercayaan Diri Dan Kecerdasan Emosional Terhadap Hasil Belajar Mahasiswa FKIP Universitas Balikpapan. 7(1), 59-77.

Komara, I. B. (2016). Hubungan antara kepercayaan diri dengan prestasi belajar dan perencanaan karir siswa. Jurnal Bimbingan Dan Konseling, 5(1), 1-10. http://journal.uad.ac.id/index.php/PSIKOPEDAGOGIA/article/view/4474.

Murtiningsih. (2017). Pengaruh Motivasi Belajar, Sarana Belajar, Dan Percaya Diri Terhadap Hasil Belajar IPS Siswa Penerima BSM (Bantuan Siswa Miskin) SMP Negeri DI Surabaya. Jurnal Ekonomi Dan Kewirausahaan, 5(2), 178-191. https://doi.org/10.26740/jepk.v5n2.p178-191.

Nugroho, B. (2015). Hubungan Antara Konsep Diri Dan Disiplin Belajar Terhadap Hasil Belajar Siswa Matematika. EKUIVALEN, 14(1), 78-83. https://doi.org/10.37729/ekuivalen.v14i1.2048.

Nur, A. S. (2016). Pengaruh Pola Asuh Orang Tua, Konsep Diri, dan Motivasi Berprestasi terhadap Prestasi Belajar Matematika Siswa Kelas IX SMP Negeri di kota Merauke. Suska Journal of Mathematics Education, 2(2), 89 - 96. https://doi.org/10.24014/sjme.v2i2.2067.

Nur, E. (2020). Peningkatan Hasil Belajar Siswa Melalui Model Pembelajaran Group Investigation Pada Materi Metabolisme Kelas MIPA XII MIPA 1 SMA NEGERI 1 MAKASSAR. Binomial, 3(2), 27-38. https://doi.org/10.46918/binomial.v3i2.668.

Nurhidayah. (2019). Pengaruh Konsep Diri dan Iklim Keluarga melalui Motivasi Berprestasi, Sikap, dan Kreativitas terhadap Hasil Belajar Matematika. Jurnal Pendidikan Matematika Dan Ilmu Pengetahuan Alam, 7(1), 35-46. https://doi.org/10.24256/jpmipa.v7i1.318.

Panjaitan, N. Q. (2020). Pengaruh Media Pembelajaran Digital Animasi dan Kepercayaan Diri terhadap Hasil Belajar Pendidikan Agama Islam Anak. Jurnal Pendidikan Anak Usia Dini, 4(2), 588-596. https://doi.org/10.31004/obsesi.v4i2.404.

Pucangan, K. dkk. (2017). Hubungan Antara Konsep Diri Dan Pola Asuh Orang Tua Terhadap Hasil Belajar IPA Siswa Kelas V SD di Desa Selat. Jurnal Mimbar PGSD Universitas Pendidikan Ganesha, 5(2), 1-10. https://doi.org/10.23887/jjpgsd.v5i2.11007.

Puspitasari, R. P. (2012). Hubungan Konsep Diri Dan Kepercayaan Diri dengan Kemampuan Komunikasi Interpersonal Pada Remaja Putus Sekolah. Psikologi: Teori \& Terapan, 3(1), 58-66. https://doi.org/10.26740/jptt.v3n1.p58-66.

Rahmadhani, S., Efronia, Y., \& Tasrif, E. (2021). Penggunaan E-Modul Di Sekolah Menengah Kejuruan Pada Mata Pelajaran Simulasi Digital. Jurnal Vokasi Informatika, 1(1), 5-9. http://javit.ppj.unp.ac.id/index.php/javit/article/view/16. 
Rozaini, N. (2017). Pengaruh Motivasi Belajar dan Kepercyaan Diri Siswa terhadap Prestasi Belajar. Jurnal Niagawan, 6(2). https://doi.org/10.24114/niaga.v6i2.8335.

Sumyati, T. (2017). Pengaruh Perhatian Orang Tua, Konsep Diri Dan Motivasi Belajar Terhadap Hasil Belajar Siswa Tentang Matematika Kelas Viii Smp Negeri Di Kecamatan Sausu Kabupaten Parigi Moutong. Mitra Sains, 5(2), 84-94.

Tjandrawinata, R. (2016). Industri 4.0 revolusi industri abad ini dan pengaruhnya pada bidang kesehatan dan bioteknologi. https://doi.org/10.5281/zenodo.49404.

Zikri. (2020). Hubungan Gaya Belajar Dan Konsep Diri Terhadap Hasil Belajar Siswa Smk Negeri 3 Solok Selatan. Jurnal Pendidikan Teknologi Dan Kejuruan, 17(2), 135-144. https://doi.org/10.23887/jptk-undiksha.v17i2.24209. 